\title{
Comparison study of resistance exercise nomenclature adopted among professionals and undergraduate physical education students
}

\section{Estudo de comparação da nomenclatura dos exercícios resistidos entre profissionais e discentes de educação física.}

\author{
Leonardo Mendes Leal de Souza \\ Gabriel Andrade Paz ${ }^{1}$ \\ Viviane Schultz Straatmann² \\ Humberto Miranda
}

Abstract - In the past few years, increased popularity of resistance training (RT) and a significant increase in the number of professionals and undergraduate in Physical Education students have been observed. A variety of names has been usually adopted for the same resistance exercise in fields. The aim of the study was to compare the resistance exercise nomenclature adopted by physical education professionals and students, and also to identify the frequencies of names adopted for these resistance exercises. The study included 191 graduate students and active physical education professionals of RT centers and gyms in the state of Rio de Janeiro, Brazil. Ten exercises traditionally performed on RT programs were selected. The results indicated that there was no association between the nomenclature of exercises and academic degree for all exercises included in the survey. However, there was significant difference ( $\mathrm{p}<0.001$ ) among response frequencies for each exercise, for the whole sample. In this sense, this study enabled identifying significant differences in the nomenclature of resistance exercises. Therefore, nomenclature standardization is essential to establish a direction and clearness in communication among professionals.

Key words: Exercise; Physical activity; PE; Strength training.

Resumo - Nos últimos anos, observa-se um aumento significativo na popularidade do treinamento de força $(T F)$, bem como aumento significativo no número de profissionais e estudantes de Educação Física no Brasil. Neste sentido, uma variedade de nomes têm sido adotadas para os exercícios resistidos. O objetivo do estudo foi comparar a nomenclatura dos exercícios resistidos adotados por profissionais de Educação Física e estudantes de graduação, bem como verificar a frequência de nomes adotados para cada exercício, respectivamente. O estudo incluiu 191 alunos de pós-graduação e profissionais de Educação Física atuantes no TF em centros e academias do estado do Rio de Janeiro, Brasil. Dez exercícios tradicionalmente realizados em programas de TF foram selecionados. Os resultados indicaram que não houve associação entre a nomenclatura dos exercícios e grau acadêmico para todos os exercícios incluidos na pesquisa. No entanto, houve diferença significativa $(p<0,001)$ entre as frequências de respostas para cada exercício, considerando toda a amostra. Neste sentido, no presente estudo, foi possivel identificar diferença significativa da nomenclatura dos exercícios resistidos. Logo, a padronização da nomenclatura é essencial para estabelecer uma direção e clareza na comunicação entre profissionais da área.

Palavras-chave: Atividade física; Educação Física; Exercício; Treinamento de força.
1. Federal University of Rio de Janeiro. Post-graduate lato-sensu program in strength training. Rio de Janeiro, RJ. Brazil.

2. State University of Rio de Janeiro. Institute of Social Medicine. Epidemiology Departament. Rio de Janeiro, RJ. Brazil.

Received: 06 May 2015 Accepted: 28 November 2015 Creative Commom 


\section{INTRODUCTION}

Resistance training (RT) has been one the most popular training modalities adopted by coaches and general population with the aim of developing physical fitness, health and/or, athletic performance ${ }^{1}$. RT prescription is based on the manipulation of several methodological variables such as exercise order, number of sets and exercise, external load, frequency, rest interval between sets and exercises, and muscle actions ${ }^{2}$. The exercise selection during RT programs often includes the use of different implements and materials such as, dumbbell, barbell, elastic band and machine ${ }^{3}$.

Despite the increased RT popularity, significant increases in the number of Physical Education (PE) professionals have been also observed in the past few years in Brazil. The scientific production in the RT area significantly increased in the last 20 years, and consequently, there has been a wide implementation of new training methods and techniques ${ }^{4-6}$. A variety of names has been adopted for the same resistance exercise $e^{7-9}$. This variety of names adopted in RT programs becomes a limiting factor in communication among RT professionals, students, general population, and also researchers from different areas ${ }^{10}$.

In addition, the lack of standardization of nomenclature may compromise the comparison of results observed among studies ${ }^{11}$. Faulkner ${ }^{12}$ showed difficulties related to inappropriate use of terminologies related to muscle contractions during dynamic or static muscle actions, and also emphasized the need for clear and concise communication to an immediate understanding among researchers. Recently, Jackson et al. ${ }^{10}$, observed a significant inconsistency in the nomenclature adopted by RT professionals through the application of a survey to 205 volunteers from different areas such as, personal trainers, clinicians, academicians, athletic trainers and strength and conditioning coaches. The authors pointed out the need to establish a standard nomenclature, given the variety of names recorded for each type of exercise. Moreover, Sawyer and Rivenes ${ }^{13}$ suggested that the knowledge about human movement is fragmented and disorganized. In this contest, the present study aimed to search whether this inconsistency remains on a different population and equipment. This context may become a limiting factor in professional practice, considering that RT professionals and researchers are often investigating different exercise performance patterns and applications.

Despite the discordance surrounding resistance exercise nomenclature, the establishment of standard nomenclatures would facilitate communication, listening and writing of researchers, and also avoid discordance among physical education researchers, student and other health professionals ${ }^{11}$. This standardization is essential to the scientific development of RT studies, considering reproducibility of procedures and data interpretation ${ }^{10}$.

Furthermore, there is a lack of evidence about the different nomenclature adopted among graduate students and RT professionals for resistance exercises. This evidence may be an important context to understand the impact 
of this variable on practice fields, considering that high school and university are the main source of scientific research. Therefore, the aim of this study was to compare the resistance exercises nomenclature adopted by physical education professionals and undergraduate students, and also to identify whether there are differences in the frequencies of names cited by the entire sample.

\section{METHODOLOGICAL PROCEDURES}

\section{Participants}

The present study included and interviewed 191 male and female undergraduate students and RT professionals at PE center and gyms in the state of Rio de Janeiro, Brazil, between August 2013 and May 2014. A cross survey was conducted with a sample selected by convenience, adopting a non-probabilistic procedure. Before volunteers answered the survey, they should meet the following inclusion criteria: a) to be a professional or undergraduate physical education student; $b$ ) to work with RT for at least 1 year at the time of the experimental procedures (e.g., professionals); c) to undergo a trainee program for at least 1 year in RT area at the time of the experimental procedures (e.g., undergraduate students). However, subjects who did not meet the above criteria were excluded from the study. All participants were request to read and sign the informed consent form. This study was approved by the Ethics Research Committee of the Federal University of Rio de Janeiro ( $\mathrm{n}^{\circ}$ 43249815.4.0000.5257) in accordance with resolution 466/12 of the National Health Council and Declaration of Helsinki.

\section{Procedures}

Researchers selected a survey for this study that used pictures of common upper and lower limb resistance exercises. This allowed collecting responses from multiple participants and locations at once. Firstly, participants were instructed to answer an interview, in which personal information such as age, work region, and academic background was obtained. In respect to academic background, professionals were instructed to report RT experience (years); and for undergraduate students, they were request to indicate their experience on RT programs as trainees (years). Secondly, participants answered an illustrated survey. The present study tried to cover exercises that usually have a diversity nomenclature on practical application. The survey consisted of 10 common RT exercises, eight of upper limbs and two of lower limbs, using implements such as barbells, dumbbells and a cable crossover equipament. Images showed the start and end of each exercise (see Figure 1 and Figure 2). For all exercises, three nomenclature options were available, and one opened alternative that was described as miscellaneous, in which the participant could write a convenient answer according to his preference. Therefore, the volunteers made a choise of only one option.

Although the investigation was made in Portuguese language, the authors translated the entire nomenclatures into English, which can be verified in the results (see Table 2 and Table 3). 


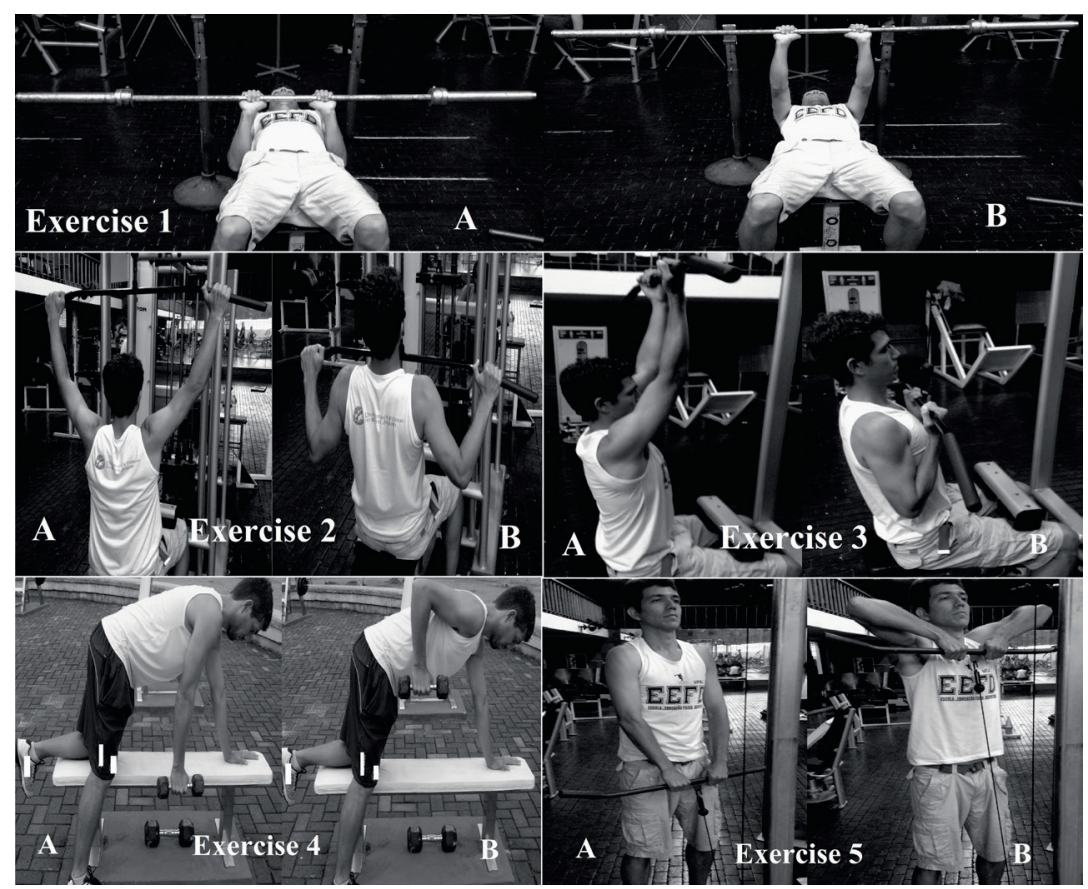

Figure 1. Exercises 1 to 5 . Two pictures are illustrating each exercise describing the beginning (A) and end (B) of the movement.

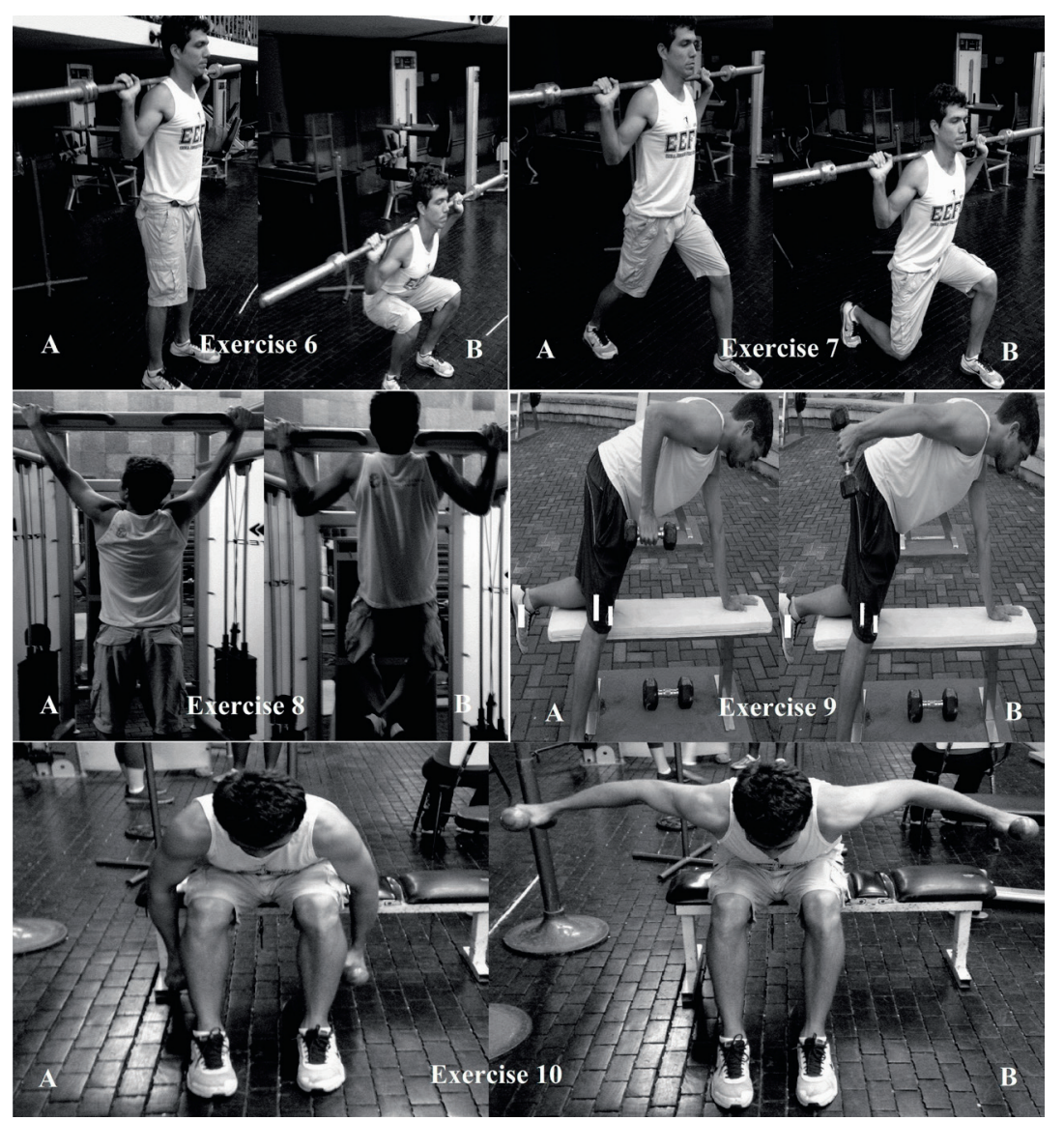

Figure 2. Exercises 6 to 10 described in figure 1 


\section{Statistical Analysis}

Descriptive analysis of data was performed using mean and standard deviation for continuous variables and frequencies for categorical variables, presented by the academic degree of participants (e.g., professionals and students). The frequency of response naming exercise was analyzed per academic degree and for the whole sample. We verified whether there are associations between response options and academic degree, and if there are associations comparing the proportions of response naming exercise in whole sample. Associations were analyzed using the $\mathrm{T}$ test with independent samples for continues variables and Chi Square test for categorical variables. The Partitioned Chi square test was used to compare proportions in the same group. Alpha level was set a priori at $\leq 0.05$. Statistical analysis was performed using SPSS 20.0 software and Win Pepi version 11:43.

\section{RESULTS}

The sample was predominantly composed of professionals and graduate students $(52.3 \%$; 47.7\%), without statistically differences between them. The average age of professionals was significantly $(\mathrm{p}<0.001)$ higher than graduate students (professionals $=30.4 \pm 7.0$ years; students $=23.8 \pm 4.2$ years). Resistance training experience was also significantly higher for professionals than for graduate students $(\mathrm{p}<0.001)$ (professionals $=78.0$ \pm 66.0 months; students $=21.8 \pm 20.1$ months).

Table 1. Demographic characteristics and resistance training experience between physical education professionals and students in Rio de Janeiro, RJ - Brazil (2013/2014).

\begin{tabular}{lccc}
\hline Varibles & Profissionals & Students & P-value \\
\hline Gender & $\mathrm{N}=100(52.3 \%)$ & $\mathrm{N}=91(47.7 \%)$ & $0.839^{*}$ \\
Male $(\%)$ & 68.1 & 66.7 & \\
Female (\%) & 31.9 & 33.3 & \\
Age (years) & $30.4( \pm 7.0)$ & $23.8( \pm 4.2)$ & $<0.001^{\star *}$ \\
RT experience (months) & $78.0( \pm 66.0)$ & $21.8( \pm 20.1)$ & $<0.001^{\star *}$ \\
\hline
\end{tabular}

${ }^{*}$ Chi-square test; ${ }^{* \star}$ T-test for independent samples. RT: Resistance training.

There was no association between naming exercises and academic degree for all exercises included in the present study (see Table 2 and Table 3). Thus, it was observed that naming exercises with the largest consensus was about 'Exercise 10', with a choice of more than $80 \%$ of individuals to name it "Dumbbell delt row". However, naming exercises with fewer consensuses was 'Exercise 6', in which $40.1 \%$ of participants adopted "Deep Squat". There was significant difference $(\mathrm{p} \leq 0.001)$ between the frequencies of names adopted for each exercises, considering the entire sample (see Table 2 and Table 3). 
Table 2. Naming response frequency pattern of upper body exercises from Rio de Janeiro, RJ, Brazil (2013/2014). The original Portuguese nomenclatures were described in parentheses. Nomenclatures are ordered from most to least cited.

\begin{tabular}{|c|c|c|c|c|}
\hline Upper limb exercises & Professionals (\%) & Students (\%) & P-value ${ }^{1}$ & All $(\%)^{2}$ \\
\hline Exercise $1(n=189)$ & & & 0.200 & \\
\hline $\begin{array}{l}\text { Lying triceps extension } \\
\text { (Tríceps Supinado) }\end{array}$ & 60.6 & 49.0 & & $55.0^{* *}$ \\
\hline $\begin{array}{l}\text { Close-grip bench press } \\
\text { (Supino Reto Pegada Fechada) }\end{array}$ & 24.2 & 35.5 & & 29.6 \\
\hline $\begin{array}{l}\text { Barbell triceps extension } \\
\text { (Supino Fechado na barra longa) }\end{array}$ & 15.2 & 15.5 & & 15.3 \\
\hline $\begin{array}{l}\text { Miscellaneous } \\
\text { (Outro) }\end{array}$ & - & - & & - \\
\hline Exercise $2(n=191)$ & & & 0.877 & \\
\hline $\begin{array}{l}\text { Pull down } \\
\text { (Puxada aberta pela frente) }\end{array}$ & 69.0 & 68.1 & & $68.6^{\star *}$ \\
\hline $\begin{array}{l}\text { Lat pull down } \\
\text { (Puxada frontal) }\end{array}$ & 16.0 & 17.6 & & 16.8 \\
\hline $\begin{array}{l}\text { Miscellaneous } \\
\text { (Outro) }\end{array}$ & 7.0 & 8.8 & & 7.9 \\
\hline $\begin{array}{l}\text { Open-grip pull down } \\
\text { (Puxada abduzida pronada) }\end{array}$ & 8.0 & 5.5 & & 6.8 \\
\hline Exercise $3(\mathrm{n}=191)$ & & & 0.330 & \\
\hline $\begin{array}{l}\text { Closed-grip front lat pull down } \\
\text { (Puxada Supinada) }\end{array}$ & 70.0 & 64.8 & & $67.5^{\star \star}$ \\
\hline $\begin{array}{l}\text { Front pull down } \\
\text { (Puxada Fechada pela frente) }\end{array}$ & 19.0 & 24.2 & & 21.5 \\
\hline $\begin{array}{l}\text { Miscellaneous } \\
\text { (Outro) }\end{array}$ & 5.0 & 8.8 & & 6.8 \\
\hline $\begin{array}{l}\text { Front inclined pull down } \\
\text { (Puxada aduzida supinada) }\end{array}$ & 6.0 & 2.2 & & 4.2 \\
\hline Exercise $4(n=191)$ & & & 0.348 & \\
\hline $\begin{array}{l}\text { One-arm dumbbell row } \\
\text { (Remada Curvada Unilateral Fechada) }\end{array}$ & 69.8 & 51.7 & & $59.9^{\star *}$ \\
\hline $\begin{array}{l}\text { Inclined dumbbell row } \\
\text { (Serrote) }\end{array}$ & 12.7 & 24.3 & & 16.8 \\
\hline $\begin{array}{l}\text { Single dumbbell rows } \\
\text { (Remada } 3 \text { apoios aduzida) }\end{array}$ & 10.7 & 18.8 & & 12.6 \\
\hline $\begin{array}{l}\text { Miscellaneous } \\
\text { (Outro) }\end{array}$ & 6.8 & 5.2 & & 11.0 \\
\hline Exercise $5(n=189)$ & & & 0.073 & \\
\hline $\begin{array}{l}\text { Upright cable row } \\
\text { (Remada alta no Cross) }\end{array}$ & 48.5 & 63.4 & & $55.6^{\star *}$ \\
\hline $\begin{array}{l}\text { Upright rows } \\
\text { (Remada alta na polia baixa) }\end{array}$ & 40.4 & 33.3 & & 37.0 \\
\hline $\begin{array}{l}\text { Miscellaneous } \\
\text { (Outro) }\end{array}$ & 7.1 & 1.1 & & 4.2 \\
\hline $\begin{array}{l}\text { High pull } \\
\text { (Remada Vertical) }\end{array}$ & 4.0 & 2.2 & & 3.2 \\
\hline Exercise $8(n=191)$ & & & 0.348 & \\
\hline $\begin{array}{l}\text { Pull up } \\
\text { (Puxada na barra fixa aberta) }\end{array}$ & 58.0 & 46.1 & & $52.4^{* *}$ \\
\hline $\begin{array}{l}\text { Closed chain pull up } \\
\text { (Barra fixa pronada) }\end{array}$ & 30.0 & 38.5 & & 34.0 \\
\hline $\begin{array}{l}\text { Pronate-grip pull up } \\
\text { (Barra fixa pronada abduzida) }\end{array}$ & 7.0 & 6.6 & & 6.8 \\
\hline $\begin{array}{l}\text { Miscellaneous } \\
\text { (Outro) }\end{array}$ & 5.0 & 8.8 & & 6.8 \\
\hline
\end{tabular}

Continue... 


\begin{tabular}{|c|c|c|c|c|}
\hline Upper limb exercises & Professionals (\%) & Students (\%) & P-value ${ }^{1}$ & All $(\%)^{2}$ \\
\hline Exercise $9(n=190)$ & & & 0.174 & \\
\hline $\begin{array}{l}\text { Triceps dumbbell kickback } \\
\text { (Tríceps coice apoiado) }\end{array}$ & 52.5 & 68.1 & & $60.0^{* *}$ \\
\hline $\begin{array}{l}\text { Seated bent-over triceps extension } \\
\text { (Extensão de cotovelos em } 3 \text { apoios) }\end{array}$ & 32.3 & 23.1 & & 27.9 \\
\hline $\begin{array}{l}\text { Bench-over dumbbell triceps extension } \\
\text { (Tríceps patada) }\end{array}$ & 9.1 & 5.5 & & 7.4 \\
\hline $\begin{array}{l}\text { Miscellaneous } \\
\text { (Outro) }\end{array}$ & 6.1 & 3.3 & & 4.7 \\
\hline Exercise $10(n=191)$ & & & 0.774 & \\
\hline $\begin{array}{l}\text { Dumbbell delt row } \\
\text { (Crucifixo Invertido sentado) }\end{array}$ & 81.0 & 80.2 & & $80.6^{\star \star}$ \\
\hline $\begin{array}{l}\text { Anti-gravity press } \\
\text { (Crucifixo dorsal sentado) }\end{array}$ & 12.0 & 12.1 & & 12.0 \\
\hline $\begin{array}{l}\text { Bench over dumbbell rear delt raise } \\
\text { (Abdução horizontal de ombros) }\end{array}$ & 6.0 & 7.7 & & 6.8 \\
\hline $\begin{array}{l}\text { Miscellaneous } \\
\text { (Outro) }\end{array}$ & 1.0 & - & & 0.5 \\
\hline
\end{tabular}

${ }^{1}$ Chi-square test for naming exercise frequency between academic degrees; ${ }^{2}$ Partitioned Chi-square test for comparing proportions of naming exercises adopted for each exercise in the whole sample; ${ }^{* *}$ Significant differences between proportions of naming exercises adopted for each exercise in the whole sample $(p \leq 0.001)$.

Table 3. Naming response frequency pattern of lower body exercises from Rio de Janeiro, RJ. Brazil (2013/2014). The original Portuguese nomenclatures were described in parentheses. Nomenclatures are ordered from most to least cited.

\begin{tabular}{|c|c|c|c|c|}
\hline Lower limb exercises & Professionals (\%) & Students (\%) & P-value ${ }^{1}$ & All $(\%)^{2}$ \\
\hline Exercise $6(n=187)$ & & & 0.814 & \\
\hline $\begin{array}{l}\text { Deep squat } \\
\text { (Agachamento profundo) }\end{array}$ & 40.8 & 39.3 & & $40.1^{\star \star}$ \\
\hline $\begin{array}{l}\text { Back squat } \\
\text { (Agachamento total) }\end{array}$ & 33.7 & 29.2 & & 31.6 \\
\hline $\begin{array}{l}\text { Miscellaneous } \\
\text { (Outro) }\end{array}$ & 15.3 & 18.0 & & 16.6 \\
\hline $\begin{array}{l}\text { Squat } \\
\text { (Afundo) }\end{array}$ & 10.2 & 13.5 & & 11.8 \\
\hline Exercise $7(n=190)$ & & & 0.299 & \\
\hline $\begin{array}{l}\text { Barbell walking lunge } \\
\text { (Agachamento unilateral) }\end{array}$ & 50.6 & 54.9 & & $52.6^{\star *}$ \\
\hline $\begin{array}{l}\text { Walking lunge } \\
\text { (Passada frontal) }\end{array}$ & 24.2 & 18.7 & & 21.6 \\
\hline $\begin{array}{l}\text { Alternate leg diagonal bound } \\
\text { (Avanço) }\end{array}$ & 13.1 & 19.8 & & 16.3 \\
\hline $\begin{array}{l}\text { Miscellaneous } \\
\text { (Outro) }\end{array}$ & 12.1 & 6.6 & & 9.5 \\
\hline
\end{tabular}

${ }^{1}$ Chi-square test for naming exercise frequency between academic degrees: ${ }^{2}$ Partitioned Chi-square test for comparing proportions of naming exercises adopted for each exercise in the whole sample; ${ }^{*}$ Significant differences between proportions of naming exercises adopted for each exercise in the whole sample $(p \leq 0.001)$.

\section{DISCUSSION}

This study investigated the nomenclature of RT exercises adopted by physical education professionals and graduate students. The main findings of the present study were the significant differences of the nomenclature of each resistance exercise cited in the survey. Additionally, there was no associa- 
tion in naming frequency between professionals and graduate students. These data are in agreement with previous studies in scientific literature ${ }^{10-12}$.

In the present study, it was observed that naming exercise with the largest consensus was 'Exercise 10', with a choice of more than $80 \%$ of participants to "Dumbbell delt row". On the other hand, naming exercise with fewer agreements was 'Exercise 6', in which the most cited nomenclature was chosen by only $40.1 \%$ of participants, adopting "Deep Squat". Furthermore, significant differences were also observed among the other naming options of each exercise. Despite the numerous investigations on RT since the last 20 years and the first studies aimed to develop terminology standards, there are still inconsistencies in the definitions of concepts and applications of strength performance variables ${ }^{14}$. These inconsistencies extend to the nomenclature adopted for resistance exercises, and may be limiting nomenclature standardization in this field. At this time, this variation in the denomination of exercises is perceived in the practice routine of RT professionals, but still little explored and discussed in scientific literature.

Recently, Jackson e al. ${ }^{10}$ investigated the naming frequencies of traditional multi-joint and free-weight exercises among different professionals who worked in RT fields (e.g., coaches, personal trainers, academicians, strength and conditioning coach, and clinicians). These authors observed inconsistency among naming responses concerning the nomenclature chosen for each exercise. They suggested that this inconsistency might create confusion for individuals being instructed by different professionals and confusion among professionals attempting to communicate with one another. The results observed by Jackson and colleagues ${ }^{10}$ corroborate with those observed in the present study, with regard to the high variation among naming frequencies of resistance exercise, regardless the academic degree.

Several studies in RT literature have designed pictures to illustrate exercises $^{15-17}$. This condition may be due to the use of inconsistent terminology associated with RT exercises. For example, in exercise number 6 of this study, previous authors have adopted different names for the same exercise, such as "squat"16, "back squat"18 and "barbell squat". Another example to be cited is the use of exercise "seated row"19, often called as "bench pull" 20 . These distinctions show the challenge of defining a possible standardization for exercise names. Thus, inconsistency of names adopted in practice among RT professionals is consequently extended to the scientific literature.

However, it is possible to propose the standardization of resistance exercise nomenclature, considering the same movement such as used a pattern of "equipment, specification, exercise" (e.g., barbell-lying bench press $)^{10}$. These naming patterns may provide clear comprehension, but there are also a few limitations. Another possibility is to use of a "specification, exercise" naming pattern (e.g., lying row, seated row or machine row). On the other hand, there probably will be a lack of information in respect to equipment that might be used for the exercise. Nordin and Frankel ${ }^{21}$ sug- 
gest the use of standardized terminology for the information of the human movement in order to clearly identify the positions and directions of the body performing the exercise. Thus, the author recommends the description of the joint axis and imaginary plans as a reference (e.g., shoulder adduction). Additional information about the instrument or equipment used, as well as the type of grip (e.g., supine, pronated or neutral) may be useful for communication among teachers, coaches and students.

The present study has some limiting factors such as sample size that does not represent the universe of professionals and students involved with RT in the metropolitan region of Rio de Janeiro, Brazil. Future studies should be developed with the purpose of reaching a representation of the population of individuals active in the RT area in a specific state or country. Another limitation refers to the survey used for the assessment of the resistance exercise nomenclature. The survey applied has not been previously tested in relation to sensitivity and reproducibility. However, considering that the scientific discussion on the topic is still embryonic, the data of the present study may help professionals and researchers to develop future studies refining the methodology procedures and assessment instruments.

Furthermore, it is important to emphasize the scientific relevance of this study, which would be considering one of the pioneers on the investigation of standardization of resistance exercises nomenclature between physical education professionals and graduate students. Therefore, the standardization of resistance exercise nomenclature adopted by professionals, teachers, students and coaches working in RT fields may benefit the communication and understanding of exercises prescribed in training programs often used in gyms, schools and also in the scientific literature. The evaluation and the identification of the current context is the first step for the development of strategies aimed at improving the scientific terminology and standardized nomenclature.

\section{Acknowledgements}

The authors thank the Foundation for State Research of Rio de Janeiro (FAPERJ).

\section{REFERENCES}

1. Miranda H, Figueiredo T, Rodrigues B, Paz GA, Simao R. Influence of exercise order on repetition performance among all possible combinations on resistance training. Res Sports Med 2013;21(4):355-66.

2. Faigenbaum AD, Myer GD. Resistance training among young athletes: safety, efficacy and injury prevention effects. Br J Sports Med 2010;44(1):56-63.

3. Warburton DE, Nicol CW, Bredin SS. Health benefits of physical activity: the evidence. Can Med Assoc J 2006;174(6):801-9.

4. Heinrich KM, Patel PM, O’Neal JL, Heinrich BS. High-intensity compared to moderate-intensity training for exercise initiation, enjoyment, adherence, and intentions: an intervention study. BMC Public Health 2014;14:789.

5. O'Hara RB, Serres J, Traver KL, Wright B, Vojta C, Eveland E. The influence of nontraditional training modalities on physical performance: review of the literature. Aviat Space Environ Med 2012;83(10):985-90. 
6. Smith MM, Sommer AJ, Starkoff BE, Devor ST. Crossfit-based high-intensity power training improves maximal aerobic fitness and body composition. J Strength Cond Res 2013;27(11):3159-72.

7. Chtara M, Chaouachi A, Levin GT, Chaouachi M, Chamari K, Amri M, et al. Effect of concurrent endurance and circuit resistance training sequence on muscular strength and power development. J Strength Cond Res 2008;22(4):1037-45.

8. Escamilla RF. Knee biomechanics of the dynamic squat exercise. Med Sci Sports Exer 2001;33(1):127-41.

9. Marshall PW, Robbins DA, Wrightson AW, Siegler JC. Acute neuromuscular and fatigue responses to the rest-pause method. J Sci Med Sport 2012;15(2):153-8

10. Jackson MC, Brown LE, Coburn JW, Judelson DA, Cullen-Carroll N. Towards standardization of the nomenclature of resistance training exercises. J Strength Cond Res 2013;27(5):1441-9.

11. Knuttgen HG, Kraemer WJ. Terminology and measurement in exercise performance. J Appl Sport Sci Res 1987;1:1-10.

12. Faulkner JA. Terminology for contractions of muscles during shortening, while isometric, and during lengthening. J Appl Physiol 2003;95(2)455-9.

13. Knudson DV. Correcting the use of the term "power" in the strength and conditioning literature. J Strength Cond Res 2009;23(6):1902-8.

14. Burke DG, Pelham TW, Holt LE. The influence of varied resistance and speed of concentric antagonistic contractions on subsequent concentric agonistic efforts. J Strength Cond Res 1999;13(3),193-7.

15. Escamilla RF, Fleisig GS, Zheng N, Lander JE, Barrentine SW, Andrews JR, et al. Effects of technique variations on knee biomechanics during the squat and leg press. Med Sci Sports Exer 2001;33(9):1552-66.

16. Queiroz BC, Cagliari MF, A morim CF, Sacco IC. Muscles activation during four Pilates core stability exercises in quadruped position. Arch Phys Med Rehabil 2010;91(1): 86-92.

17. Shimano T, Kraemer WJ, Spiering BA, Volek JS, Hatfield DL, Silvestre R, et al. Relationship between the number of repetitions and selected percentages of one repetition maximum in free weight exercises in trained and untrained men. J Strength Cond Res 2006;20(4):819-23.

18. Paz GA, Willardson JM, Simão R, Miranda H. Effect of different antagonist protocols on repetition performance and muscle activation. Med Sportiva 2013;17(3):106-12.

19. Robbins DW, Young WB, Behm DG. The effect of an upper-body agonistantagonist resistance training protocol on volume load and efficiency. J Strength Cond Res 2010;24(10):2632-40.

20. Nordin M, Frankel VH. Basic biomechanics of the musculoskeletal system: Lippincott Williams \& Wilkins. 2012.

CORRESPONDING AUTHOR

Gabriel Andrade Paz

Av. Carlos Chagas Filho, Cidade

Universitária

21941-590 - Rio de Janeiro, RJ.

Brazil.

E-mail: gabriel.andrade.paz@gmail. com 